\title{
KAJIAN MODULUS TANAH BERDASARKAN UJI LAPANGAN DAN UJI LABORATORIUM
}

\author{
Cindarto Lie $^{1}$ \\ PT. CND Geoteknika \\ Jl. Pesantren No.168, Cibabat, Kota Cimahi \\ e-mail: cindarto@gmail.com
}

\begin{abstract}
ABSTRAK
Penelitian ini mengkaji tentang soil modulus (modulus tanah) yaitu suatu faktor yang menghubungkan antara besarnya stress/tegangan dan strain/regangan yang terjadi pada tanah. Soil modulus adalah salah satu parameter utamadalam analisa geoteknik yang menggunakan metoda elemen hingga atau finite elemen method (FEM). Soil modulus biasanya ditentukan melalui uji laboratorium atau uji in-situ di lapangan.Ada berbagai macam dan ragamsoil modulus, tergantung dari kondisinya antara lain kondisi pembebanannya apakah static atau dynamic, drained atau undrained, level tegangan dan regangan yang terjadi, tegangan keliling dan seterusnya.
\end{abstract}

Kata kunci: modulus tanah.

\section{ABSTRACT}

This research was conducted to study about soil modulus, a factor that connect the magnitude of stres sand strain that occur in soil.Soil modulus is one of the main parameters in geotechnical analysis using the Finite Element Method (FEM). Soil modulus is usually determined through laboratory test or in-situ test in field. depends on the condition, there are various kinds of soil modulus, including loading conditions whether static or dynamic, drained or un-drained, stress and strain levels that occur, perimeter stress, an so on.

Keywords: soil modulus.

\section{PENDAHULUAN}

Seiring dengan makin pesatnya kemajuan teknologi komputasi, telah membuat analisa numerik turut berkembang dengan pesat juga.Salah satu yang sangat berkembang saat ini adalah analisa geoteknik dengan Finite Element Method(FEM), yang mana sangat bermanfaat dalam menyelesaikan persoalan geoteknik yang kompleks, terutama untuk menyelesaikan problem interaksi antara tanah dan struktur bangunan. Beberapa program FEM yang popular saat ini antara lain PLAXIS, MIDAS dan FLAC.

Dalam analisa geoteknik dengan FEM diperlukan input/data masukan yang baik ketelitiannya, agar diperoleh output/hasil yang teliti dan realistis, salah satu parameter utama dari analisa FEM adalah Soil Modulus, yaitu suatu koefisien yang menghubungkan antara besarnya tegangan dan regangan yang terjadi pada tanah.

Soil Modulus adalah parameter tanah yang paling sulit diperkirakan karena tergantung dari banyak faktor seperti misalnya kondisi pembebanan statik atau dinamik, drained atau un-drained, level tegangan dan penentuannya tentu saja harus disesuaikan 
dengan kondisiyang terjadi di lapangan. Seminar bidang kajian ini akan membahas modulus tanah berdasarkan uji laboratorium dan uji di lapangan.

\section{LATAR BELAKANG}

Dalam analisa FEM interaksi antar elemen dinyatakan dalam perubahan regangan dan tegangan (stress dan strain) yang terjadi pada masing-masing elemen akibat beban luar, hal ini yang menjadikan regangan dan tegangan adalah faktor utama dalam analisa FEM. Soil modulus atau modulus tanah, E adalah modulus atau angka yang menghubungkan antara regangan dan tegangan dalam elemen-elemen tanah tersebut. Tergantung dari cara pembebanan seperti loading, un-loading, drained, un-drained, stress level dan statik atau dinamik yang menentukan soil modulus yang tepat untuk dipergunakan dalam analisa, sehingga pemilihan dan penentuan nilai soil modulus adalah suatu hal yang sangat penting dalam analisa FEM.

Dalam bab selanjutnya akan dibahas mengenai jenis-jenis soil modulus yang dipakai dalam analisa FEM dan bagaimana mengukurnya baik di lapangan maupun di laboratorium.

\section{RAGAM SOIL MODULUS}

Karena grafik tegangan dan regangan tanah pada umumnya bukan grafik yang linier, maka beragam modulus dapat ditentukan dari grafik tersebut.

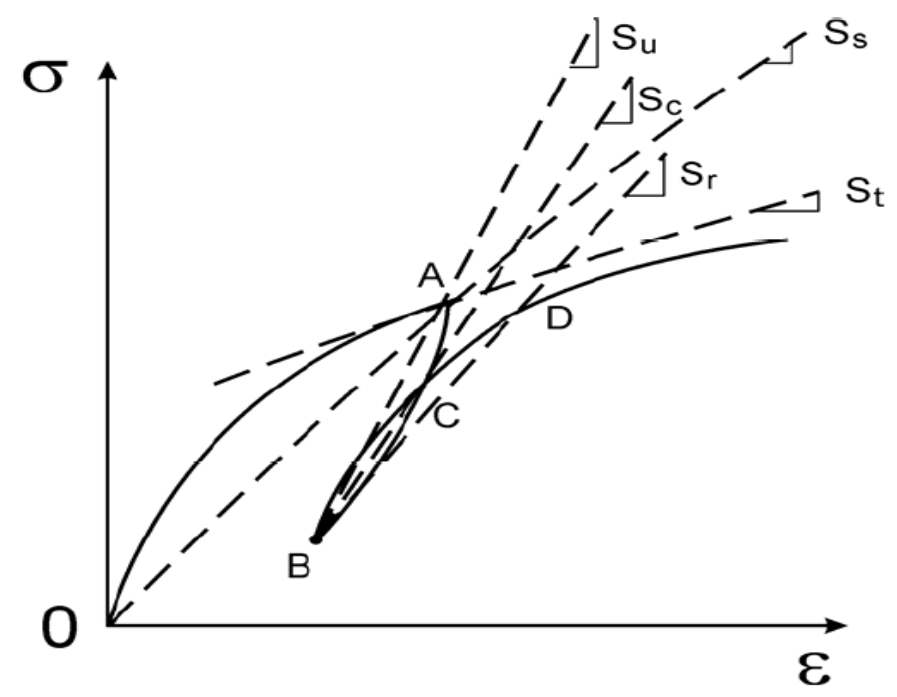

Gambar 1. Definisi Soil Modulus (JL. Briaud, 2004) 
Dengan mengacu pada grafik tegangan dan regangan pada Gambar 1, beberapa ragam soil modulus dapat diturunkan antara lain;

- Secant Modulus Es,yang merupakan kemiringan garis OA atau Slope Ss, yang dipergunakan untuk memperkirakan penurunan fondasi pada saat pertama kali menerima pembebanan.

- Tangent Modulus Et,yang ditarik sebagai garis singgung dari salah satu titik tertentu dalam grafik tegangan regangan atau Slope St, yang dipergunakan untuk menghitung penurunan yang terjadi akibat penambahan beban pada fondasi.

- Unloading Modulus/Resilient Modulus Eu, yang merupakan kemiringan garis AB atau Slope $\mathrm{Su}$, yang dipergunakan untuk untuk menghitung heave (penyembulan tanah dasar galian) atau rebound dari pavement setelah terlindas ban truk yang lewat.

- Reload Modulus Er, yang merupakan kemiringan garis BD atau Slope Sr, yang dipergunakan untuk menghitung penurunan pada dasar galian pada saat beban bangunan membebani kembali permukaan dasar galian atau penurunan dari pavement akibat pembebanan kembali dari ban truk yang lewat.

- Cyclic Modulus Ec,yang merupakan kemiringan garis BC atau Slope Sc, yang dipergunakan untuk menghitung deformasi struktur fondasi akibat beban cyclic seperti gaya ombak atau gempa.

\section{FAKTOR YANG MEMPENGARUHI NILAI SOIL MODULUS}

Beberapa faktor yang mempengaruhi besarnya nilai Soil Modulus antara lain:

\subsection{Kepadatan tanah (Density)}

Semakin tinggi kepadatan (density) tanah maka semakin tinggi juga Soil Modulusnya. Kepadatan tanah disini diukur dengan kepadatan kering (dry density)yang merupakan perbandingan berat tanah kering dengan volume tanah basah. Selain itu juga dapat diukur melalui porositas tanah yang merupakan nilai perbandingan antara volume void dengan volume total tanah basah.

\subsection{Struktur tanah (Soil Stucture)}

Struktur tanah yang dimaksud adalah bagaimana susunan butiran partikel tanah, pada tanah berbutir kasar atau pasiran apakah struktur tanahnya loose atau dense. Sedangkan pada tanah lempungan strukturnya dispersed atau flocculated. Perlu diketahui bahwa dua buah contoh tanah dengan dry density yang sama tetapi berbeda strukturnya, akan berbeda juga Soil Modulusnya. Ini menjelaskan mengapa dalam pengambilan contoh tanah berbutir kasar di lapangan dan kemudian membentuknya kembali di 
laboratorium, walaupun sudah mempunyai dry density yang sama, tetap diperoleh hasil modulus tanah yang berbeda sama sekali.

\subsection{Kadar air (Water Content)}

Kadar air mempunyai pengaruh yang sangat besar pada Soil Modulus. Pada tanah berbutir halus (cohesive soil), pada kadar air yang rendah, air merekatkan antara partikel tanah dan meningkatkan effective stress melalui efek suction dan tegangan kapiler air tanah. Sehingga pada kadar air yang rendah tanah lempung menunjukkan Soil Modulus yang tinggi. Ini menjelaskan mengapa tanah lempung menyusut dan mengeras pada saat dikeringkan.

Lain halnya pada tanah berbutir kasar, upaya pemadatan kurang efisien pada kadar air yang rendah, dan menjadi efisien setelah penambahan kadar air,karena air memberikan lubrikasi antar butiran tanah. Sehingga pada tanah berbutir kasar, kadar air yang rendah membuat Soil Modulus juga rendah dan meningkat seiring dengan bertambah kadar airnya, namun penambahan ini akan berhenti sampai pada kadar air optimum saja, karena air yang berlebihan akan memperbesar jarak antar butiran tanah, sehingga menurunkan nilai Soil Modulus dan meningkatkan kompresibilitas tanah berbutir kasar tersebut.

\subsection{Riwayat Pembebanan (Stress History)}

Ini menyangkut sejarah pembebanan yang pernah dialami oleh suatu lapisan tanah. Jika lapisan tanah pada masa lalunya pernah mengalami tekanan yang lebih besar dari pada tekanan yang ada sekarang ini maka lapisan tanah disebut overconsolidated (OC). Jika suatu lapisan tanah belum pernah mengalami tekanan yang lebih besar dari pada yang ada sekarang ini maka lapisan tanah disebut normally consolidated (NC). Tanah over consolidated biasanya mempunyai Soil Modulus yang lebih tinggi dari pada tanah normally consolidated, dikarenakan pembebanan pada tanah OC ada pada jalur reloading dari grafik stress strain sedangkan tanah $\mathrm{NC}$ ada di jalur awal loading. Sebagian tanah ada yang masih dalam proses konsolidasi akibat berat sendirinya, tanah ini disebut under consolidated. Lapisan tanah under consolidated ini mempunyai nilai Soil Modulus yang sangat rendah.

\subsection{Sementasi (Cementation)}

Yang dimaksud dengan sementasi adalah daya rekat antar partikel tanah. Pada tanah berbutir halus, kadar air yang rendah menghasilkan gaya suction yang cukup kuat, yang menunjukkan adanya rekatan antar partikel tanah yang sangat kuat. Akan tetapi efek suction ini bersifat sementara karena akan hilang seiring dengan peningkatan kadar air tanah. Daya rekat lainnya adalah akibat sementasi kimia berupa deposisi calcium atau 
silika pada bidang kontak antar partikel tanah. Sementasi tersebut di atas jelas berpengaruh dan akan meningkatkan Soil Modulus.

\subsection{Faktor Pembebanan (Loading factor)}

Faktor pembebanan berupa besarnya tegangan dan besarnya regangan yang terjadi pada tanah sangat mempengaruhi besarnya Soil Modulus yang mewakili dalam analisa stress strain dari tanah tersebut.
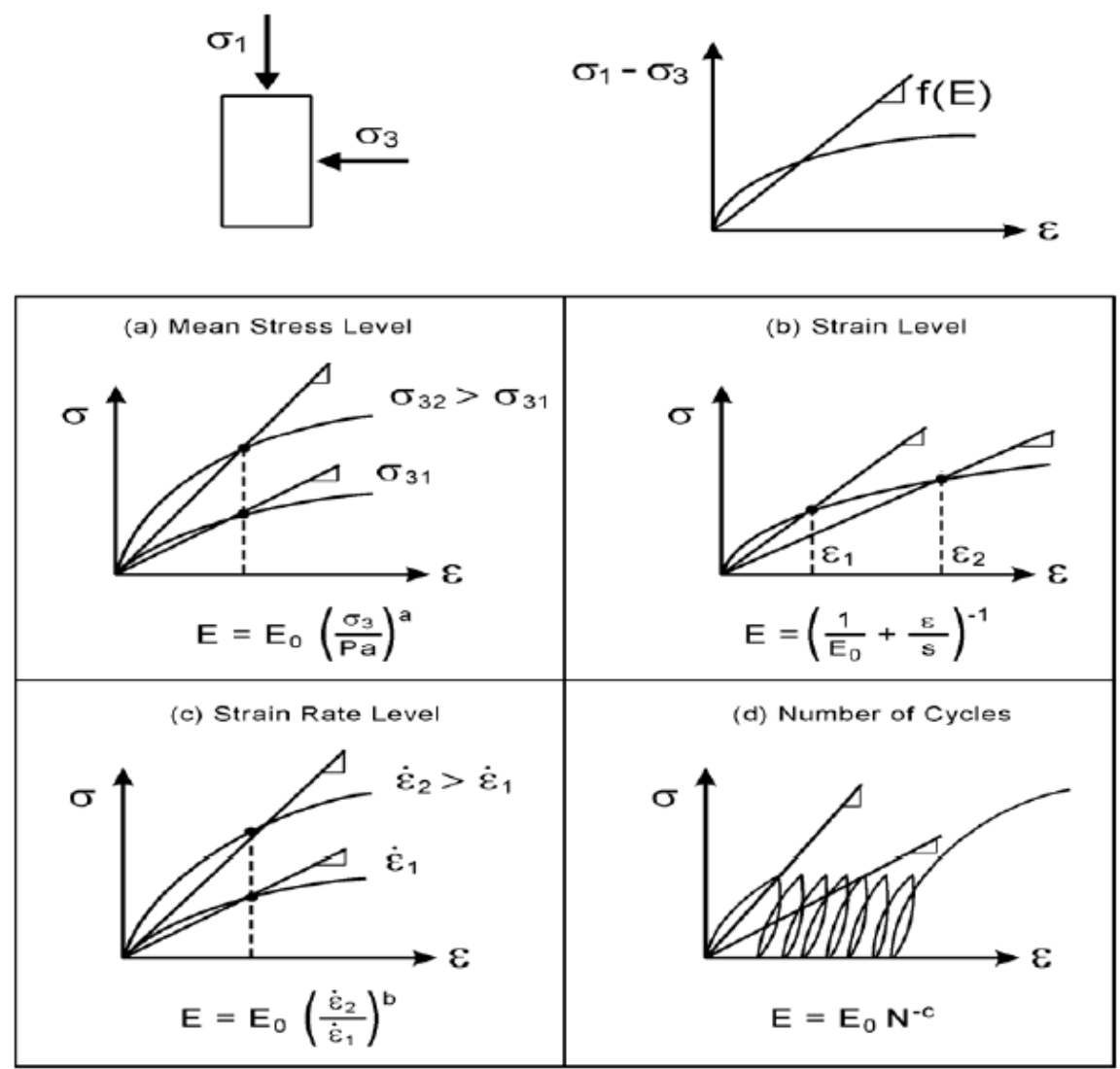

Gambar 2.Pengaruh Faktor Pembebanan pada Soil Modulus (JL. Briaud, 2004)

- Gambar 2a. Semakin besar tegangan keliling (mean stress) tanah maka semakin besar juga Soil Modulusnya.

Menurut Kondner, $\mathrm{E}=\mathrm{Eo}\left(\sigma_{3} / \mathrm{Pa}\right)^{\mathrm{a}}$

Dimana:

$\mathrm{E} \quad=$ Secant Modulus

Eo = Secant Modulus pada tegangan keliling 1 Atmosfir

$\mathrm{Pa}=$ Tekanan Atmosfir

$\mathrm{A}=0.5$

Kajian Modulus Tanah Berdasarkan Uji Lapangan dan Uji

Laboratorium (Cindarto Lie) 
- Gambar 2b. Dalam banyak kasus semakin besar regangan maka Soil Modulus semakin kecil. Hal ini tidak terjadi pada uji konsolidasi, karena semakin besar regangan semakin besar nilai Soil Modulusnya, hal ini karena efek confining dari ring oedometer.

Menurut Duncan, $\mathrm{E}=(1 / \mathrm{Eo}+\varepsilon / \mathrm{s})^{-1}$

Dimana:

$\mathrm{E} \quad=$ Secant Modulus

$\varepsilon \quad=$ Regangan

Eo = Initial Tangent Modulus, atau Secant Modulus pada saat $\varepsilon=0$

$\mathrm{S} \quad=$ Nilai Asymptotic Tegangan untuk regangan tak terhingga

- Gambar 2c. Soil Modulus dipengaruhi oleh kecepatan regangan (strain rate), semakin cepat regangan yang diberikan maka semakin tinggi nilai Soil Modulusnya, demikian juga sebaliknya.

Menurut research di Texas A\&M University, $\mathrm{E}=\mathrm{Eo}\left(\varepsilon_{2} / \varepsilon_{1}\right)^{\mathrm{b}}$

Dimana:

$\mathrm{E} \quad=$ Secant Modulus

Eo = Secant Modulusyang diperoleh pada strain rate standard

b = tangent dari kurva Log Modulus vs Log Strain

$\mathrm{b} \quad=0,02$ untuk tanah lempung kaku

$\mathrm{b} \quad=0.1$ untuk tanah lempung sangat lunak

b $\quad=0,01-0,03$ untuk tanah pasir

- Gambar 2d. Soil Modulus dipengaruhi oleh jumlah siklus pembebanan yang terjadi (cyclic) semakin besar jumlah siklus pembebanan maka semakin rendah nilai Soil Modulusnya, demikian juga sebaliknya.

Menurut research di Texas A\&M University, $\mathrm{E}=\mathrm{Eo} \mathrm{N}^{-\mathrm{c}}$

Dimana:

$\mathrm{E} \quad=$ Secant Modulus

Eo = Secant Modulus yang diperoleh pada strain rate standard

c $\quad=-0,1-(-0,3)$

- Kondisi drainase pada saat pembebanan juga berpengaruh pada besarnya Soil Modulus, sehingga Soil Modulus dibedakan antara Modulus Undrain ataukah Modulus Drain. Undrain artinya pembebanan terjadi dengan cepat sehingga terjadi peningkatan tekanan air pori. Sebaliknya pada kondisi drain, pembebanan berlangsung sangat lambat sehingga tekanan air pori terdesipasi dengan baik dan tidak terjadi peningkatan tekanan air pori. 


\subsection{Aplikasi di Lapangan}

Tidak diragukan bahwa parameter Soil Modulus sangat berguna dalam melakukan analisa geoteknik dari berbagai aplikasi bangunan sipil di lapangan, bisa difahami bahwa pemakaian Soil Modulus bervariasi nilainya, tergantung pada masingmasing kondisi dan aplikasinya di lapangan. Menurut Briaud (2013) berikut di bawah ini diuraikan secara ringkas pemakaian Soil Modulus dalam berbagai aplikasi di lapangan;

\section{- Pada kasus perencanaan fondasi dangkal}

Besarnya tegangan rata-rata di dasar fondasi dangkal biasanya berkisar antara 100 sampai $200 \mathrm{kPa}$. Besarnya regangan vertikal (vertical strain) kira-kira lebih kecil atau sama dengan $1 \%$ dan biasanya dihubungkan dengan penurunan maksimum sebesar $25 \mathrm{~mm}$. Kecepatan pembebanan berlangsung sangat lambat, mulai dari tahap konstruksi dan kemudian beban bangunan tetap membebani dalam kurun waktu yang lama. Beban cyclic hanya terjadi karena beban sementara karena angin atau gempa.

\section{- Pada kasus perencanaan fondasi dalam}

Pada fondasi dalam besarnya tegangan keliling rata-rata bervariasi karena skin friction terjadi di sepanjang tiang fondasi. Besarnya strain yang terjadi pada ujung tiang fondasi dalam biasanya lebih kecil dibanding strain yang terjadi pada fondasi dangkal karena sebagian besar beban bangunan telah dipikul skin friction sebelum sampai pada ujung tiang fondasi. Kecepatan pembebanan berlangsung sangat lambat, mulai dari tahap konstruksi yang berbulan-bulan dan kemudian beban bangunan tetap membebani dalam kurun waktu yang lama.Beban cyclic hanya terjadi karena beban sementara akibatgempa atau beban ombak pada tiang fondasi dermaga dan jembatan. Karena fondasi dalam sangat luas penggunaannyapadaberbagai jenis tanah dan berbagai bangunan dengan banyak variasi pembebanan, maka Soil Modulus yang dipergunakan dalam analisa fondasi dalam jauh lebih bervariasi dibanding yang dipakai dalam analisa fondasi dangkal.

\section{- Pada kasus stabilitas lereng dan dinding penahan tanah}

Pergerakan tanah yang terjadi pada stabilitas lereng berhubungan dengan deformasi dari masa tanah yang diakibatkan oleh berat sendirinya. Oleh karena itu besarnya tegangan yang terjadi berhubungan dengan tegangan akibat gravitasi. Regangan yang terjadi biasanya relatif kecil dan pada awalnya strain rate (kecepatan regangan) tergantung pada kecepatan konstruksi lereng dan selanjutnya kecepatan deformasi jangka panjang (long term deformation rate) selama masa service lereng atau dinding penahan tanah tersebut. Beban cyclic hanya terjadi pada saat gempa.Untuk perencanaan lereng dan dinding penahan tanah yang layak, soil modulus yang dipakai cenderung lebih besar dari soil modulus pada perencanaan fondasi karena besarnya strain cenderung lebih kecil. 


\section{- Pada kasus perkerasan jalan (pavement)}

Besarnya tegangan keliling yang terjadi pada sub-grade relatif sangat kecil. Tekanan yang terjadi pada perkerasan jalan berkisar antara 200kPa untuk ban mobil, $500 \mathrm{kPa}$ untuk ban truk dan $1700 \mathrm{kPa}$ untuk ban pesawat terbang. Dalam desain, direncanakan tegangan vertikal yang terjadi pada permukaan sub-grade kurang lebih hanya $10 \%$ dari tekanan akibat ban pada permukaan perkerasan jalan. Besarnya regangan atau strain yang terjadi pada sub-grade sangat kecil karena dari semula tujuan dari perencanaan perkerasan jalan adalah untuk mencegah terjadinya deformasi vertikal dalam jangka panjang dari sub-grade. Besarnya regangan (strain) yang terjadi pada permukaan sub-grade lebih kecil atau sama dengan 0,001. Kecepatan pembebanan sangat tinggi, hal ini berhubungan dengan kecepatan kendaraan yang lewat.Waktu pembebanan sangat singkat dan diperkirakan dalam mili-detik untuk mobil yang bergerak dengan kecepatan $100 \mathrm{~km} / \mathrm{jam}$.Tetapi dihitung dalam jam-jaman untuk pesawat yang diparkir di hanggar.Jumlah cycle pembebanan berhubungan erat dengan jumlah lalu lintas yang melewati permukaan perkerasan jalan tersebut selama umur pelayanannya.

\section{PENGUKURAN SOIL MODULUS}

Soil Modulus dapat diukur secara langsung in-situ di lapangan atau melalui pengujian contoh tanah tak terganggu di laboratorium.Kedua cara pengukuran soil modulus tersebut masing-masing memiliki kelebihan dan kekurangan

Tabel 1.Kelebihan dan Kekurangan Pengukuran Soil Modulus di Lapangan dan di Laboratorium

\begin{tabular}{|c|c|}
\hline Soil modulus dengan in-situ testing & Soil modulus dengan uji laboratorium \\
\hline $\begin{array}{l}\text { Kelebihan } \\
\text { - Praktis pelaksanaannya } \\
\text { - Derajat ketergangguan tanah relative } \\
\text { lebih sedikit } \\
\text { - Dalam beberapa aspek bisa lebih } \\
\text { ekonomis }\end{array}$ & $\begin{array}{l}\text { Kelebihan } \\
\text { - Kondisi pembebanan, besarnya serta } \\
\text { kecepatan pembebanan dapat } \\
\text { disimulasikan dalam pengujian di } \\
\text { laboratorium } \\
\text { - Tidak memerlukan persamaan korelasi }\end{array}$ \\
\hline
\end{tabular}


Tabel 1. Kelebihan dan Kekurangan Pengukuran Soil Modulus di Lapangan dan di Laboratorium (lanjutan)

\begin{tabular}{|c|c|}
\hline Soil modulus dengan in-situ testing & Soil modulus dengan uji laboratorium \\
\hline Kekurangan & Kekurangan \\
\hline $\begin{array}{l}\text { - Perlu persamaan korelasi untuk } \\
\text { menghubungkannya dengan nilai soil } \\
\text { modulus yang akan dipergunakan dalam }\end{array}$ & $\begin{array}{l}\text { - Perlu kualitas contoh tanah yang baik } \\
\text { untuk memperoleh kwalitas data yang } \\
\text { baik }\end{array}$ \\
\hline analisa & - Biaya pengambilan contoh tanah \\
\hline $\begin{array}{l}\text { - Persamaan korelasi belum tentu sesuai } \\
\text { karena perbedaan jenis tanah yang } \\
\text { dihadapi }\end{array}$ & dengan kwalitas yang baik cukup mahal \\
\hline
\end{tabular}

Lepas daripada kekurangan dan kelebihan dari pengukuran soil modulus baik di lapangan maupun di Laboratorium, setiap analisa FEM yang menghasilkan nilai deformasi, sebisa mungkin dilakukan pengukuran deformasi aktual di lapangan untuk mengkalibrasi parameter-parameter tanah yang telah dipergunakan. Untuk itu bilamana memungkinkan disarankan untuk menggunakan kedua metode pengukuran baik di lapangan dan dilaboratorium.

\subsection{Pengukuran di laboratorium}

Untuk pengujian Soil Modulus di laboratorium, contoh tanah diambil dari lapangan dan diuji di laboratorium.Kendala pengukuran Soil Modulus di laboratorium adalah memperoleh contoh tanah yang mewakili kondisi yang ada di lapangan, biasanya contoh tanah sedikit banyak telah mengalami gangguan baik pada saat pengambilan, transportasi dan pencetakan contoh tanah sebelum pengujian.Selain itu ada keterbatasan untuk mensimulasikan tegangan keliling yang identik dengan kondisi natural contoh tanah di lapangan.Namun demikian pengukuran Soil Modulus di laboratorium tetap memberikan manfaat yang besar sepanjang disadari adanya kemungkinan penyimpangan akibat dari beberapa gangguan tersebut di atas.

\subsubsection{Triaxial Test}

Nilai modulus Young dapat ditentukan dengan memplotkan nilai dari tegangan deviator $(\Delta \sigma)$ dan $(\varepsilon)$ yang didapat dari hasil uji triaxial test. Berikut di bawah ini diberikan contoh penentuan $\mathrm{E}_{50}$ dari hasil pengujian Triaxial CU. 


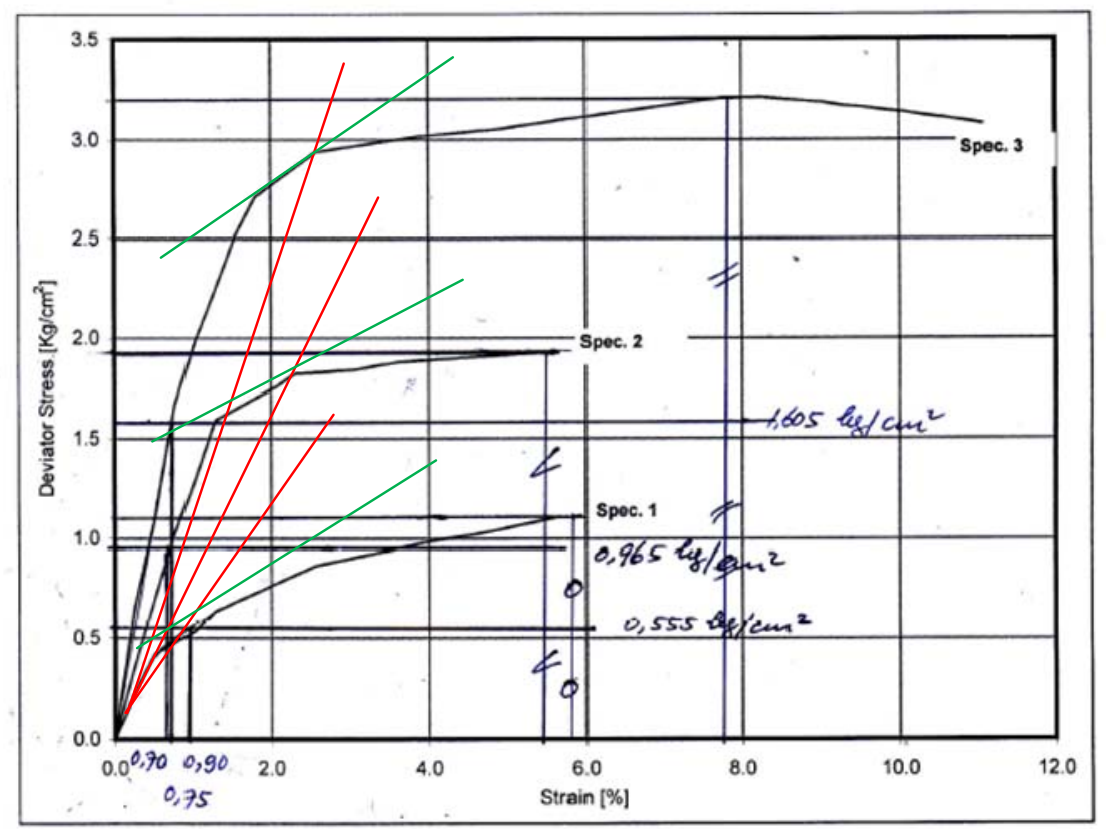

Gambar 3. Contoh Perhitungan Soil Modulus dari Grafik Stress Strain Uji Triaxial Secant Modulus

$$
\begin{aligned}
& \text { Es }(1)=2,4 / 2 \%=120 \mathrm{~kg} / \mathrm{cm}^{2} \\
& \text { Es (2) }=1,6 / 2 \%=80 \mathrm{~kg} / \mathrm{cm}^{2} \\
& \text { Es }(3)=1.1 / 2 \%=55 \mathrm{~kg} / \mathrm{cm}^{2}
\end{aligned}
$$

\section{Tangent Modulus}

$$
\begin{aligned}
& \text { Et (1) }=0,55 / 2 \%=27,5 \mathrm{~kg} / \mathrm{cm}^{2} \\
& \operatorname{Et}(2)=0,50 / 2 \%=25 \mathrm{~kg} / \mathrm{cm}^{2} \\
& \operatorname{Et}(3)=0,45 / 2 \%=22,5 \mathrm{~kg} / \mathrm{cm}^{2}
\end{aligned}
$$

Modulus Young Rencana

$$
\begin{aligned}
& \mathrm{E}_{50}(1)=1,605 / 0,75 \%=214 \mathrm{~kg} / \mathrm{cm}^{2} \\
& \mathrm{E}_{50}(2)=0,965 / 0,7 \%=138 \mathrm{~kg} / \mathrm{cm}^{2} \\
& \mathrm{E}_{50}(3)=0,555 / 0,9 \%=62 \mathrm{~kg} / \mathrm{cm}^{2}
\end{aligned}
$$

Selanjutnya nilai $\mathrm{E}_{50}$ desain dapat ditentukan dengan memplotkan nilai $\mathrm{E}_{50}$ dan $\sigma_{3}{ }_{3}$ seperti terlihat pada grafik dibawah ini: 


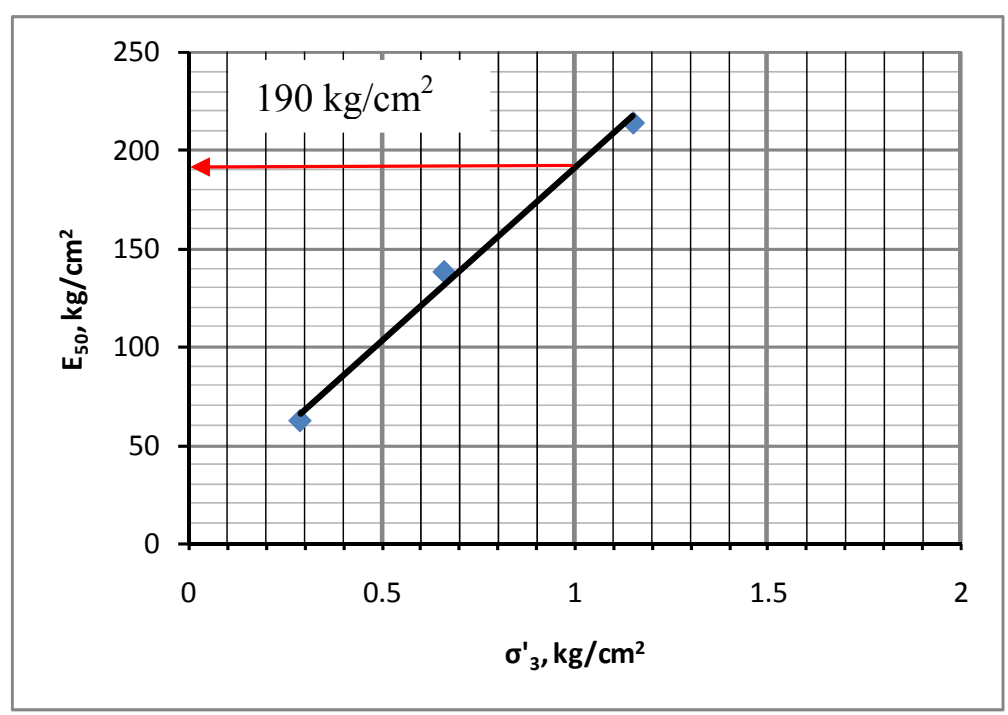

Gambar 4. Contoh Grafik $E_{50}$ Reference

Modulus Youngrencana ( $\mathrm{E}_{50}$ design) diambil pada saat tekanan efektif sebesar 1 bar $\left(1 \mathrm{~kg} / \mathrm{cm}^{2}\right)$ dan memberikan nilai $\mathrm{E}_{50}$ reference sebesar $190 \mathrm{~kg} / \mathrm{cm} 2=19000 \mathrm{kPa}$.

\subsubsection{Oedometer Test}

Soil modulus dapat ditentukan juga dengan alat uji konsolidasi tanah atau oedometer. Dari uji ini diperoleh modulus terkekang/constraint soil modulus. Contoh penentuannya diberikan pada gambar berikut di bawah ini:

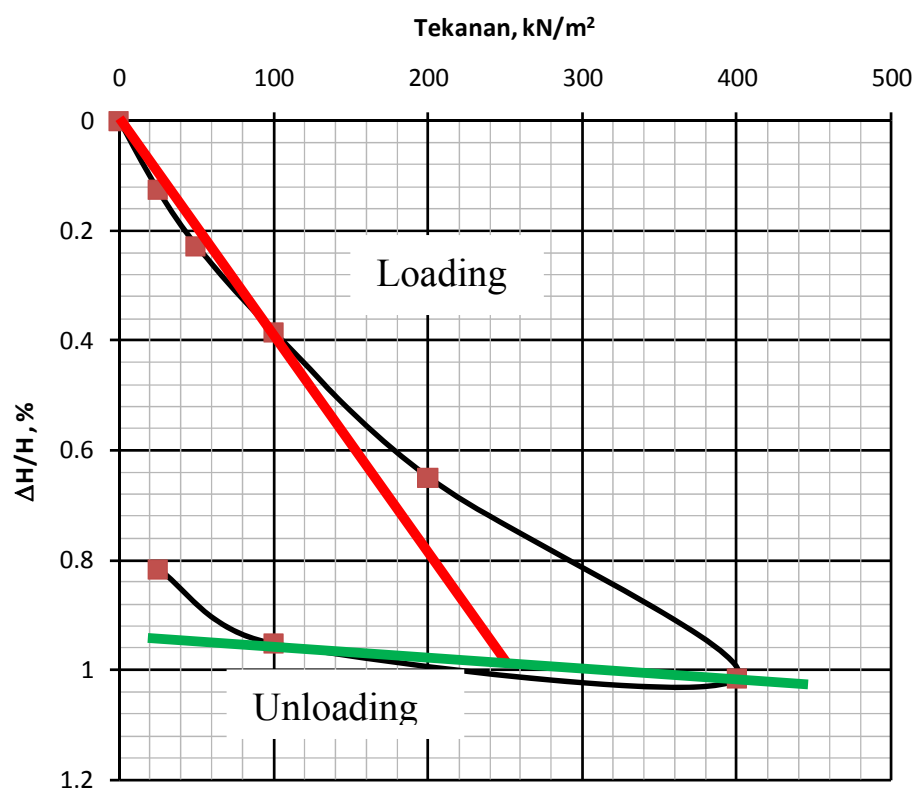

Gambar 5. Grafik Hubungan antara Tegangan dengan Pemampatan Tanah

Kajian Modulus Tanah Berdasarkan Uji Lapangan dan Uji 
Modulus terkekang pada saat terjadi pembebanan (loading);

$$
\begin{aligned}
& \mathrm{P}(1)=100 \mathrm{kN} / \mathrm{m}^{2} \Delta \mathrm{H} / \mathrm{H}(1)=0,4 \% \\
& \mathrm{P}(2)=0 \mathrm{~kg} / \mathrm{cm}^{2} \Delta \mathrm{H} / \mathrm{H}(2)=0 \%
\end{aligned}
$$$$
\text { Eoed }=(100-0) /(0,4 \%-0 \%)=25000 \mathrm{kPa}(\text { loading })
$$

Modulus terkekang pada saat terjadi pelepasan beban (unloading);

$$
\begin{aligned}
& \mathrm{P}(1)=400 \mathrm{kN} / \mathrm{m}^{2} \Delta \mathrm{H} / \mathrm{H}(1)=1,02 \% \\
& \mathrm{P}(2)=100 \mathrm{kN} / \mathrm{m}^{2} \Delta \mathrm{H} / \mathrm{H}(1)=0,96 \% \\
& \text { Eoed }=(400-100) /(1,02 \%-0,96 \%)=500000 \mathrm{kN} / \mathrm{m}^{2} \text { (unloading) }
\end{aligned}
$$

\subsection{Pengukuran di lapangan (in-situ)}

\subsubsection{Pressuremeter test}

Pressuremeter adalah alat berbentuk silindris dengan selubung karet dengan baja didalamnya. Cara menggunakannya yaitu dengan mengembangkan membran setelah probe masuk ke dalam tanah atau batuan dan tekanan dan peralihan (displacement) diamati selama pengujian yang kemudian data-data tersebut digunakanuntuk menghasilkan kurva tegangan-regangan yang berguna untuk pengambilan parameterparameter desain.
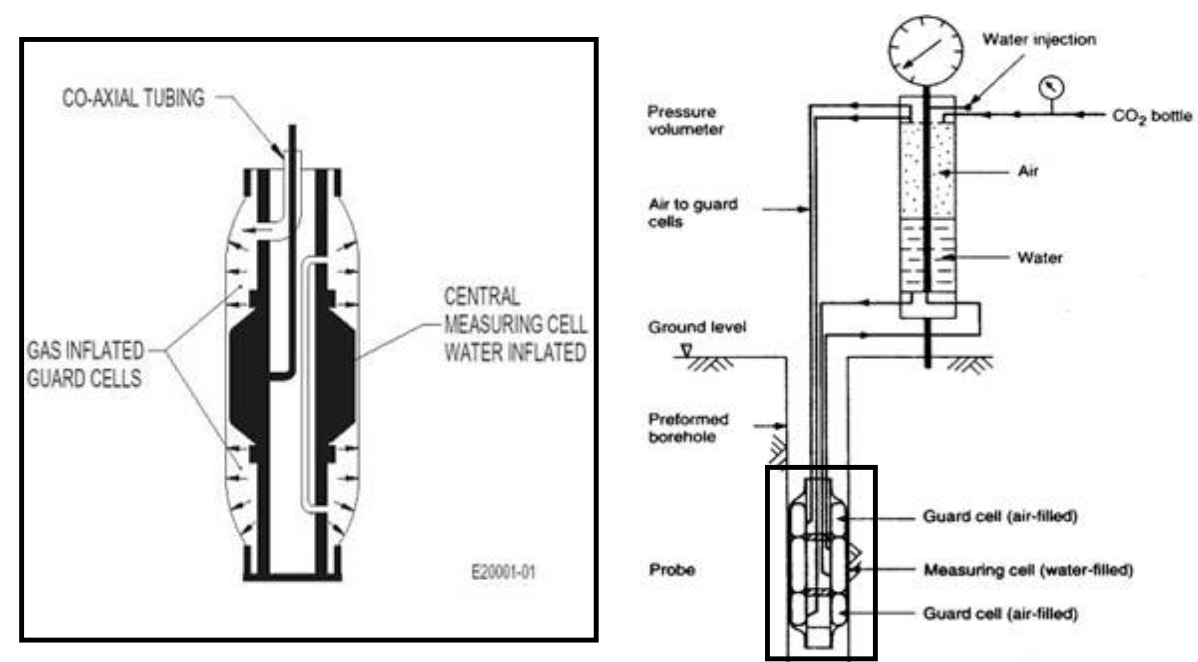

Gambar 6. Sketsa Diagram Uji Pressuremeter darı Menard (atter Gibdon and Anderson, 1961)

Pengujian pressuremeter dibagi menjadi 3 tahapan yaitu:

1. Fase 1, yaitu tahap pengembangan awal balon pressuremeter hingga mengenai dan menekan dinding lubang bor hingga tercapai kondisi stress-straintanah seperti kondisi tanah sebelum dilakukan pemboran (kondisi at-rest). 
2. Fase 2, meliputi pengembangan pressuremeter selanjutnya dimana kondisi stressstrain tanah berkembang dari zone elastic menjadi plastic.

3. Fase 3, tahap setelah terlampauinya zone elastic dan memasuki zona plastic sampai dengan kekuatan batas.

Gibson dan Anderson juga mendefinisikan bahwa limit pressure tercapai pada saat volume pengembangan telah mencapai $2 \mathrm{x}$ volume initial.

Soil modulus yang diperoleh dari pengujian Pressuremeter (E $\left.\mathrm{E}_{\mathrm{PMT}}\right)$ ditentukan melalui teori Cavity Expansion dan aplikasinya untuk pengembangan rongga silindris yang tebal dengan asumsi bahwa tanah bersifat linier elastic yang dapat dideskripsikan dengan Young modulus (E) dan Poisson ratio (v).

$\mathrm{E}_{P M T}=2 \cdot(1+\mathrm{v}) \cdot\left(\mathrm{V}_{\mathrm{o}}+\mathrm{V}_{\mathrm{m}}\right) \cdot \frac{\Delta E}{\Delta P}$

Dimana;

$\mathrm{Vm}=\frac{\mathrm{V} \theta+\mathrm{VF}}{2}$

$\Delta \mathrm{P}=\mathrm{P}_{\mathrm{f}}-\mathrm{P}_{0}$

$\Delta \mathrm{V}=\mathrm{V}_{\mathrm{f}}-\mathrm{V}_{0}$

$v=$ Poisson's ratio $\sim 0.33$ untukkondisi drained

Berikut di bawah ini diberikan contoh hasil uji Pressuremeter dimana ditentukan $\mathrm{E}_{\mathrm{PMT}}$ pada kondisi elastik dan plastis (after failure).

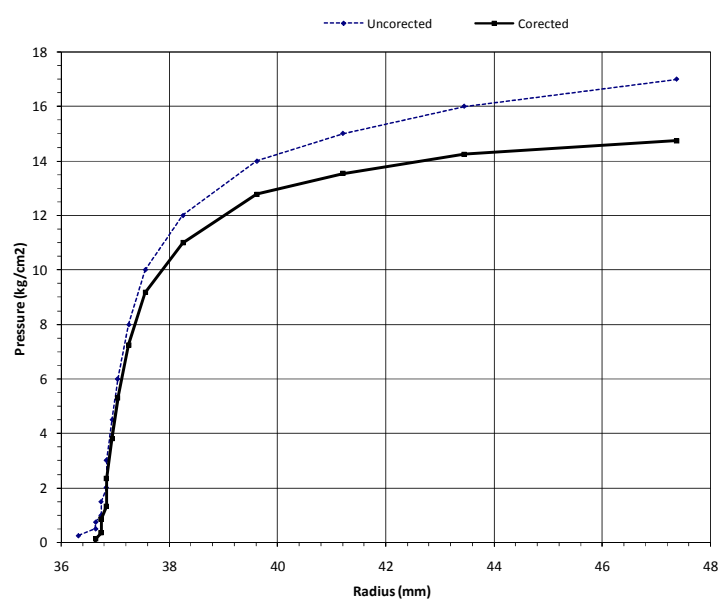

Gambar 7. Plot Pressure vs. Radius 
Tabel 2. Hasil uji Pressuremeter test

\begin{tabular}{|c|c|c|c|c|c|c|c|c|c|}
\hline \multicolumn{4}{|c|}{ Point on curve considered } & \multirow{3}{*}{$\begin{array}{c}\mathrm{Km} \\
\mathrm{dp} \\
\mathrm{dr} \\
\mathrm{kg} / \mathrm{cm}^{3}\end{array}$} & \multirow{3}{*}{$\begin{array}{c}\mathrm{m} \\
\left(\mathrm{r}_{1}+\mathrm{r}_{2}\right) \\
2 \\
\mathrm{~cm}\end{array}$} & \multirow{3}{*}{$\begin{array}{c}\text { Poisson's } \\
u\end{array}$} & \multirow{3}{*}{$\begin{array}{c}\text { Deformation } \\
\text { Modulus }\left(E_{M}\right) \\
(1+v) . K m \cdot m \\
\mathrm{~kg} / \mathrm{cm}^{2}\end{array}$} & \multirow{3}{*}{$\begin{array}{c}\text { ShearMod.(G) } \\
\text { E/2.(1+v) } \\
\mathrm{kg} / \mathrm{cm}^{2}\end{array}$} & \multirow{3}{*}{ Remarks } \\
\hline \multicolumn{2}{|c|}{1} & \multicolumn{2}{|c|}{2} & & & & & & \\
\hline $\begin{array}{c}p_{1} \\
\mathrm{~kg} / \mathrm{cm}^{2}\end{array}$ & $\begin{array}{l}\mathrm{r}_{1} \\
\mathrm{~cm}\end{array}$ & $\begin{array}{c}p_{2} \\
\mathrm{~kg} / \mathrm{cm}^{2}\end{array}$ & $\begin{array}{l}\mathrm{r}_{2} \\
\mathrm{~cm}\end{array}$ & & & & & & \\
\hline 1.33 & 3.68 & 5.29 & 3.70 & 192.94 & 3.69 & 0.30 & 926.63 & 356.40 & Initial Condition \\
\hline 14.25 & 4.35 & 14.75 & 4.74 & 1.27 & 4.54 & 0.30 & 7.52 & 2.89 & Plastic Condition \\
\hline
\end{tabular}

\subsubsection{Plate Loading test}

Pengujian Plate Loading Test atau PLT (ASTM D-1196) adalah salah satu pengujian di lapangan yang sederhana dan paling tua. Pengujian PLT dilakukan dengan cara membebani secara bertahap sebuah pelat berdiameter tertentu $(30-60 \mathrm{~cm})$ yang diletakkan di atas lapisan tanah yangakan diuji.

Hasil pengujian berupa grafik hubungan antara tekanan normal rata-rata pada bidang kontak antara pelat $(\sigma)$ dengan permukaan tanah terhadap penurunan yang terjadi pada pelat (s).

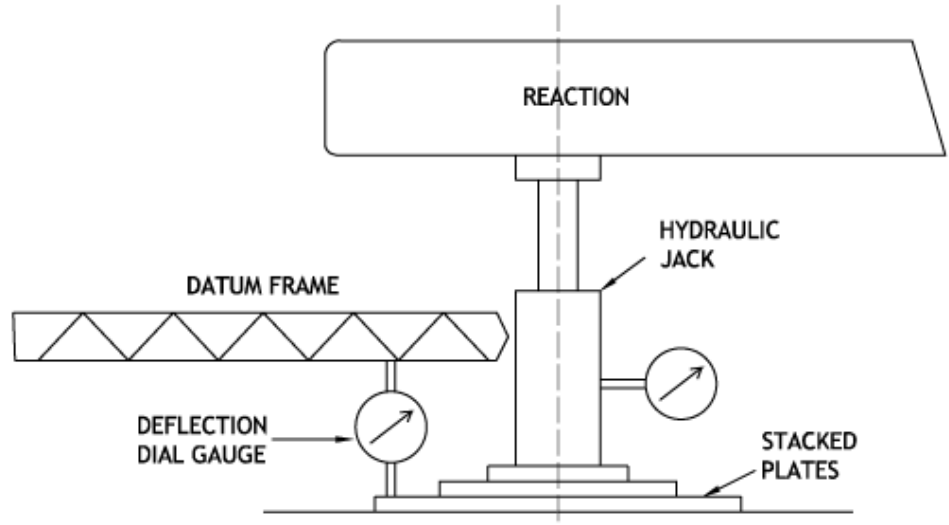

Gambar 8. Skematis Pengujian Plate Loading Test atau PLT (ASTM D-1196) 


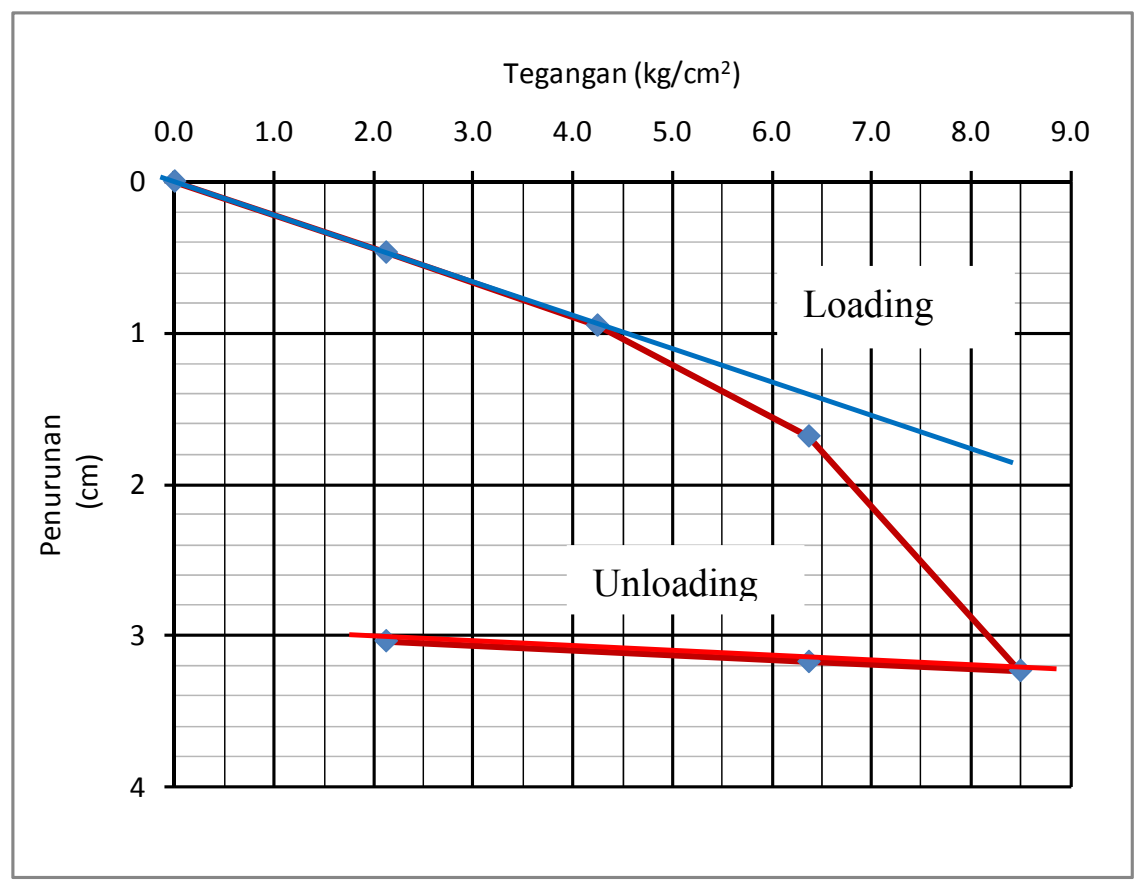

Gambar 9.Contoh Grafik Hasil Pengujian Plate Loading Test (Bendungan Wein, Kaltim)

Dari Plate Loading Test tersebut dapat diperoleh parameter sebagai berikut:

Subgrade Modulus pada saat terjadi pembebanan (loading):

$$
\begin{aligned}
& \mathrm{P}(1)=0 \mathrm{~kg} / \mathrm{cm}^{2} \quad \text { Penurunan, } \mathrm{S}(1)=0 \mathrm{~cm} \\
& \mathrm{P}(2)=4,5 \mathrm{~kg} / \mathrm{cm}^{2} \quad \text { Penurunan, } \mathrm{S}(2)=1,2 \mathrm{~cm} \\
& \mathrm{Ks}=\Delta \mathrm{P} / \Delta \mathrm{s} \\
& \mathrm{Ks}=(4,5-0) /(1,2-0)=3,75 \mathrm{~kg} / \mathrm{cm}^{3} \\
& \mathrm{Eo}=0,25 \mathrm{Ks} \pi \mathrm{D}\left(1-\mathrm{v}^{2}\right) \\
& \mathrm{D}=40 \mathrm{~cm} \text { \&Poisson ratio, } \mathrm{u}=0,3 \\
& \mathrm{Eo}=0,25 \times 3,75 \times 3,14 \times 40\left(1-0,3^{2}\right) \\
& \mathrm{Eo}=107 \mathrm{~kg} / \mathrm{cm}^{2}
\end{aligned}
$$

Subgrade Modulus pada saat terjadi pelepasan beban (unloading);

$$
\begin{aligned}
& \mathrm{P}(1)=2 \mathrm{~kg} / \mathrm{cm}^{2} \quad \begin{array}{l}
\text { Penurunan }(1)=3 \mathrm{~cm} \\
\mathrm{P}(2)=8,5 \mathrm{~kg} / \mathrm{cm}^{2}
\end{array} \\
& \mathrm{Ks}=(8,5-2) /(3,2-3)=32,5 \mathrm{~kg} / \mathrm{cm}^{2} / \mathrm{cm} \\
& \mathrm{Eo}=0,25 \mathrm{Ks} \pi \mathrm{D}\left(1-\mathrm{v}^{2}\right) \\
& \mathrm{Eo}=0,25 \times 32,5 \times 3,14 \times 40\left(1-0,3^{2}\right) \\
& \text { Eo }=928,65 \mathrm{~kg} / \mathrm{cm}^{2} \text { (unloading) }
\end{aligned}
$$


Perlu diketahui bahwa Ks bukan soil parameter, karena nilainya tergantung pada besarnya diameter pelat yang dipergunakan untuk pengujian. Sehingga baik parameter Ks maupun Eo sangat tergantung dari diameter pelat uji.

\subsubsection{SPT test}

Standard Penetration Test (SPT) dilakukan bersamaan dengan pelaksanaan pemboran tanah. Pengujian SPT dilakukan pada setiap interval kedalaman tertentu, biasanya antara 1 - 3meter.SPT test dilakukan dengan cara menghitung jumlah pukulan palu pemukul yang diperlukanuntuk mendesak tabung contoh Split Spoon Sampler berdiameter 2" sedalam $30 \mathrm{~cm}$ ke dalam tanah. Berat palu pemukul yang dipergunakan adalah $63,5 \mathrm{~kg}$ dengan tinggi jatuh $75 \mathrm{~cm}$. Penghitungan jumlah pukulan dilakukan 3 kali yaitu setiappenetrasi $15 \mathrm{~cm}$. Nilai SPT diperoleh dengan menjumlahkan jumlah pukulan yangdiperlukan pada $15 \mathrm{~cm}$ penetrasi kedua dan ketiga. Hasil pengujian Standard Penetration Test (SPT) ini biasanya disajikan dalam bentuk grafik pada Log Bor Inti.

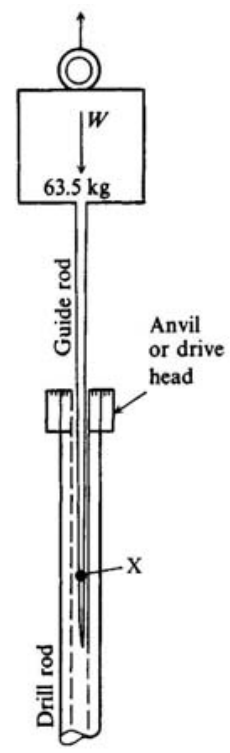

Gambar 10. Skematik Standard Penetration Test

Sebagai contoh upaya menghubungkan antara hasil uji SPT di lapangan dengan Soil Modulus telah dilakukan oleh Gouw Tjie Liong dkk (2011).Penelitian dilakukan terhadap terhadap tanah lempung dan lanau di Jakarta dan dikorelasikan dengan berbagai soil modulus yang biasa diperlukan untuk analisa FEM.

Berikut ini adalah korelasi yang dihasilkan dari penelitian tersebut;
$\mathrm{E}_{50}(\mathrm{kPa})=354 \cdot \mathrm{N}_{(60)}$
$\left(0<\mathrm{N}_{(60)}<41, \mathrm{R}^{2}=0.64\right)$
$\mathrm{E}_{\text {oed }}(\mathrm{kPa})=303 . \mathrm{N}_{(60)}$
$\left(0<\mathrm{N}_{(60)}<46, \mathrm{R}^{2}=0.64\right)$
$\mathrm{E}_{\text {PMT }}(\mathrm{kPa})=890 . \mathrm{N}_{(60)}$
$\left(0<\mathrm{N}_{(60)}<48, \mathrm{R}^{2}=0.84\right)$ 
Dimana;

$$
\begin{array}{ll}
\mathrm{E}_{50} & =\text { Soil modulus yang diperoleh dari Triaxial test } \\
\mathrm{E}_{\text {oed }} & =\text { Soil modulus yang diperoleh dari uji konsolidasi } \\
\mathrm{E}_{\mathrm{PMT}} & =\text { Soil modulus yang diperoleh dari Pressuremeter test } \\
\mathrm{N}_{1(60)} & =\text { Nilai SPT N yang telah dinormalisasi untuk tekanan efektif overburden sebesar } \\
& 1 \mathrm{~kg} / \mathrm{cm}^{2}(100 \mathrm{kPa}) \\
\mathrm{N}_{1(60)} & =\mathrm{C}_{\mathrm{n}} \cdot \mathrm{N}_{60}, \mathrm{C}_{\mathrm{n}}=\sqrt{\frac{12}{\sigma w}}, \sigma^{\prime} v=\text { tekanan vertikal efektif } \\
\mathrm{N}_{60} & =\text { normalized } \mathrm{N}-\mathrm{SPT} \text { value to an effective hammering energy of } 60 \% \\
\mathrm{~N}_{60} & =\alpha \cdot \beta \cdot \gamma \cdot \mathrm{N}_{\text {field }} \cdot \frac{\text { Ey }}{\text { E60 }} \\
\alpha & =\text { Rod length correction } \\
\beta & =\text { Standard sampler correction } \\
\gamma & =\text { Borehole diameter correction (see Table } 1 \text { for } \alpha, \beta, \gamma) \\
\mathrm{N}_{\text {field }} & =\text { Field SPT blow count (n value) } \\
\mathrm{E} \gamma & =\text { SPT effective energy }
\end{array}
$$

\begin{tabular}{|c|c|c|}
\hline \multirow[t]{4}{*}{ Rod length $(\alpha)$} & $>100 \mathrm{~m}$ & 1.00 \\
\hline & $6-10 m$ & 0.95 \\
\hline & $4-6 m$ & 0.85 \\
\hline & $3-4 m$ & 0.75 \\
\hline \multicolumn{2}{|l|}{ Standard sampler $(\beta)$} & 1.00 \\
\hline \multicolumn{2}{|c|}{ US sampler without liners $(\beta)$} & 1.20 \\
\hline \multirow[t]{3}{*}{ Borehole diameter $(\gamma)$} & $65-115 \mathrm{~mm}$ & 1.00 \\
\hline & $150 \mathrm{~mm}$ & 1.05 \\
\hline & $200 \mathrm{~mm}$ & 1.15 \\
\hline
\end{tabular}

Tabel 3. Nilai koefisien $\alpha, \beta$ dan $\gamma$

\section{SIMPULAN}

Berdasarkan kajian tersebut di atas, mengenai soil modulus dapat ditarik kesimpulan sebagai berikut di bawah ini:

1. Soil modulus adalah unsur utama dalam analisa FEM. Dengan berbagai nama dan sebutan, pada dasarnya Soil modulus adalah faktoryang menghubungkan nilai stress dan strain atau tegangan dan regangan dari suatu elemen tanah. 
2. Untuk memperoleh nilai tegangan dan regangan yang tepat dalam analisa FEM dan deformasi lainnya diperlukan nilai soil modulus yang relevan. Relevan terhadap faktor faktor yang mempengaruhi besarnya soil modulus tersebut.

3. Berbagai faktoryang mempengaruhi besarnya soil modulus antara lain:

a. Kondisi tanah itu sendiri seperti kadar air, kepadatan, struktur tanah, sementasi, riwayat pembebanan.

b. Kondisi pembebanan, besar kecilnya, apakah cepat atau lambat, drain atau undrain, statis atau dinamis dst.

c. Anisotrophy

d. Scale effect

4. Soil modulus dapat diukur baik di laboratorium maupun langsung di lapangan (in-situ test), kedua cara pengukuran ini masing-masing mempunyai kelebihan dan kekurangannya. Tetapi pada dasarnya selama factor-factor tersebut di atas (point 3) telah dipertimbangkan dalam pengukuran soil modulus maka nilai soil modulus seharusnya akan memberikan nilai yang relevan dalam analisa FEM.

5. Mengingat pengukuran soil modulus memberikan nilai yang semu (apparent) maka sangat dianjurkan untuk melakukan kalibrasi soil parameter dalam mode geoteknik dengan hasil pengukuran tegangan dan regangan yang actual terjadi di lapangan dengan menggunakan instrumentasi geoteknik seperti inclinometer dan extensometer.

\section{DAFTAR PUSTAKA}

1. Laurence D. Wesley.\& Satyawan Pranyoto 2010.Mekanika Tanah untuk Tanah Endapandan Residu (Soil Mechanics for Sedimentary and Residual Soils). Andi, Yogyakarta, Indonesia.

2. Alam Singh. 1981. Soil Engineering in Theory and Practice. McGraw-Hill, inc., USA.

3. Jean-Louis Briaud. 2013. Geotechnical Engineering of Unsaturated and Saturated Soils. Joh Wiley \& Sons, Inc. New Jersey

4. A.H. Hamman, M. Eliwa, 2013. Comparison between results of dynamic \& static moduli of soil determined by different method. Housing and Building National Research Center, Elsevier.

5. Marawan M. Shahien, Ahmed farouk, 2013. Estimation of Deformation Modulus of Gravelly Soils using Dynamic Cone Penetration Tests. Ain Shams Engineering Journal, Ain Sham University, Egypt

1. Gouw Tjie Liong,Hiasinta,.2011. Soil Stiffness for Jakarta Silty and Clayey Soils. Pertemuan Ilmiah Tahunan XIV, HATTI, Yogyakarta, 10-11 February 2011. 